\title{
Quantification of $\operatorname{recA}$ gene expression as an indicator of repair potential in marine bacterioplankton communities of Antarctica
}

\author{
Melissa G. Booth ${ }^{1, *}$, LeAnna Hutchinson ${ }^{2}$, Margaret Brumsted ${ }^{2}$, Peter Aas ${ }^{2}$, \\ Richard B. Coffin ${ }^{3}$, Roswell C. Downer $\mathrm{Jr}^{4}$, Cheryl A. Kelley ${ }^{5}, \mathrm{M}$. Maille Lyons ${ }^{2}$, \\ J. Dean Pakulski ${ }^{2}$, Sonya L. Holder Sandvik ${ }^{6}$, Wade H. Jeffrey ${ }^{2}$, Robert V. Miller ${ }^{1, * *}$ \\ ${ }^{1}$ Department of Microbiology and Molecular Genetics, Oklahoma State University, Stillwater, Oklahoma 74078, USA \\ ${ }^{2}$ Center for Environmental Diagnosis and Bioremediation, University of West Florida, Pensacola, Florida 32514, USA \\ ${ }^{3}$ Naval Research Laboratory, Washington, DC, Washington 20375, USA \\ ${ }^{4}$ Department of Oceanography, Texas A\&M University, College Station, Texas 77840, USA \\ ${ }^{5}$ Department of Geological Sciences, University of Missouri, Columbia, Missouri 65211, USA \\ ${ }^{6}$ National Research Council, c/o U.S. EPA, Gulf Breeze, Florida 32561, USA
}

\begin{abstract}
Marine bacteria in surface waters must cope daily with the damaging effects of exposure to solar radiation (containing both UV-A and UV-B wavelengths), which produces lesions in their DNA. As the stratospheric ozone layer is depleted, these coping mechanisms are likely to play an even more important role in the viability of marine bacterial communities. The recA gene is ubiquitous among eubacteria and is highly conserved both in nucleotide and amino acid sequence. Besides its role in generalized recombination, the gene's translational product, RecA, is the regulator of 'dark repair' activity (DNA-repair mechanisms that do not require visible light as a cofactor). We have taken advantage of this function and used recA gene expression as a barometer of the DNAdamage repair capacity of bacterial assemblages in the Southern Ocean. Studies were conducted in the Gerlache Strait, Antarctica, in the austral springs of 1995 and 1996. Analysis of both recA mRNA and RecA protein extracted from natural communities indicated that the level of expression of this gene varied in a diel fashion, suggesting an increased repair capacity in these organisms. These included an early morning rise in RecA levels followed by a plateau or even a reduction in RecA concentration during the remainder of the day. A much greater increase in RecA was consistently observed after sunset, followed by a constant decrease during the night. Microcosm experiments with a $\operatorname{Rec}^{+}$Gerlache Strait $\gamma$-proteobacteria isolate, RM11001, demonstrated a similar diel pattern of expression. These studies demonstrate the usefulness of RecA as a biological indicator of DNA repair capacity in natural bacterial assemblages. They indicate that 'dark repair' of DNA damage is an important coping mechanism for bacteria in the marine environment of Antarctica.
\end{abstract}

KEY WORDS: Southern Ocean · Antarctica - Solar UV radiation - DNA repair · Marine bacterioplankton communities $\cdot$ recA gene $\cdot \operatorname{RecA}$ protein

\section{INTRODUCTION}

In recent years there has been increased interest in the effects of ultraviolet (UV) radiation on marine com-

\footnotetext{
${ }^{*}$ Present address: Skidaway Institute of Oceanography, Savannah, Georgia 31405, USA

${ }^{* *}$ Corresponding author. E-mail: rum67@okstate.edu
}

munities in response to the annual depletion of ozone over Antarctica (Farman et al. 1985, Solomon et al. 1986). Column ozone levels may decrease by over $60 \%$, resulting in several-fold increases in UV radiation during episodic ozone thinning. Ozone depletion occurs during the austral spring (Stamnes et al. 1990), and there is concern that the springtime 'bloom' in the Southern Ocean may be significantly affected and alter primary production in this region. 
Solar UV radiation consists of UV-C (100 to $280 \mathrm{~nm}$ ), UV-B (280 to $320 \mathrm{~nm}$ ), and UV-A (320 to $400 \mathrm{~nm}$ ) (Peak \& Peak 1983). UV-C is environmentally irrelevant because it does not penetrate the earth's atmosphere. UV-B is selectively absorbed by ozone and increases significantly during ozone depletion events (Stolarski 1988). Longer UV-A wavelengths are unaffected by changes in column ozone (Stolarski 1988).

Recent evidence suggests that UV-B may have significant effects on marine microbial communities. Phytoplankton and primary production have been the focus of the majority of previous studies (Bidigare 1989, Marchant et al. 1991, Holm-Hansen et al. 1993, Schick et al. 1995, Forster \& Lüning 1996, Herrmann et al. 1997, Holm-Hansen 1997, Zagarese et al. 1997), while significantly less is known about UV radiation effects on bacterioplankton in the Southern Ocean. Helbling et al. (1995) reported that viability, based on colony-forming units (CFU), of a natural bacterial assemblage and 2 marine isolates from Antarctic waters decreased significantly when exposed to UV-R. The inhibition of viability due to UV-A was consistently higher than UV-B in all cases, but, interestingly, there were marked differences in the tolerance of the natural assemblage and the 2 isolates to solar radiation, suggesting a heterogeneity in sensitivity among species.

Studies conducted in other regions demonstrated that bacterioplankton may be significantly impacted by solar UV radiation. Bacterial production is inhibited by UV radiation (Herndl et al. 1993, Aas et al. 1996, Visser et al. 1999). UV-B-induced DNA damage has been reported to be higher in small bacterioplankton cells than in larger eukaryotic plankton (Jeffrey et al. 1996a) and to fluctuate in a diel pattern (Jeffrey et al. 1996b). Damage was seen to accumulate during the afternoon hours but then be repaired between sunset and the following sunrise. Repair of DNA damage at night suggests the presence of active dark repair processes (those that do not require visible light as a cofactor). The RecA protein is the primary regulatory factor for the SOS global regulon. This regulon includes the genes for all known dark repair mechanisms in bacteria (Miller 2000). The ubiquitous nature and high genetic conservation of this gene makes recA an ideal candidate for studies of UV-induced gene expression in the environment (Miller et al. 1999).

Until a bacterium's DNA is damaged by UV-R or another stimulus, the genes of the SOS regulon are either silent or only minimally transcribed due to the binding of the LexA repression protein to SOS promoters (Walker 1984). When damage reaches a level that inhibits DNA replication, the RecA protein is activated to stimulate the autocatalysis of the LexA protein. This eliminates repression of the SOS promoters and allows transcription of SOS genes (Miller 2000). Because the $r e c A$ gene is itself regulated as part of the SOS geneexpression system, measurement of the concentration of RecA protein in the cell allows monitoring of its effective repair capacity (Miller et al. 1999). Under induced conditions, RecA rapidly becomes one of the most abundant proteins in the cell (Gudas \& Pardee 1976).

Since RecA is a key element in bacterial response to DNA damage, monitoring of the expression of this gene should provide valuable insight into the mechanism by which marine bacterioplankton respond to changes in incident solar UV radiation. In this study, we have investigated the appropriateness of quantification of RecA protein as an indicator of UV-radiation stress in bacterioplankton in the Southern Ocean. The results demonstrate that recA expression is useful as an indicator of the repair of UV radiation-induced damage in heterotrophic marine bacterioplankton. Our results profile the repair potential among members of the Antarctic bacterial community.

\section{MATERIALS AND METHODS}

Research site. Samples were collected during 2 research cruises aboard the RV 'Polar Duke' in the Gerlache Strait, Antarctica, at approximately $64^{\circ} 10^{\prime} \mathrm{S}$, $61^{\circ} 50^{\prime} \mathrm{W}$ (Fig. 1). The Gerlache Strait separates the Palmer Archipelago from the Antarctic peninsula.

Sample collection. To determine the diel profiles of RecA protein concentrations in natural Antarctic bacterioplankton, surface samples were collected every $2 \mathrm{~h}$ for a $24 \mathrm{~h}$ period. Four experiments were conducted in 1995 and 5 in 1996. Experiments were done on October 21/22, October 26/27, October 31/November 1 and November 3/4 in 1995. In 1996, they were carried out on October 4/5, October 8/9, October 13/14, October $19 / 20$, and October 22/23.

Surface seawater samples for RecA analysis of natural Antarctic bacterioplankton were collected via a teflon-lined submersible pump. Seawater samples were filtered through a $0.8 \mu \mathrm{m}$ pore-size filter (Gelman Supor, Gelman, Ann Arbor, Michigan). Cells remaining in the filtrate were then collected onto $142 \mathrm{~mm}$ Gelman Supor $0.2 \mu \mathrm{m}$ pore-size filters. The filters were frozen at $-80^{\circ} \mathrm{C}$ for later analysis.

Bacterial strains. RM11001 was isolated from seawater collected at the Gerlache Straits. Escherichia coli Strain AB1157 is a well-studied K-12 strain (Miller \& $\mathrm{Ku}$ 1978). It is $\operatorname{Rec}^{+}$and produces a wild-type RecA protein.

Microcosm studies. Experiments were conducted to determine induction of recA gene expression in RM11001 as well as to compare photoreactivation and dark repair in this bacterium. Polyethylene bags (Whirl- 


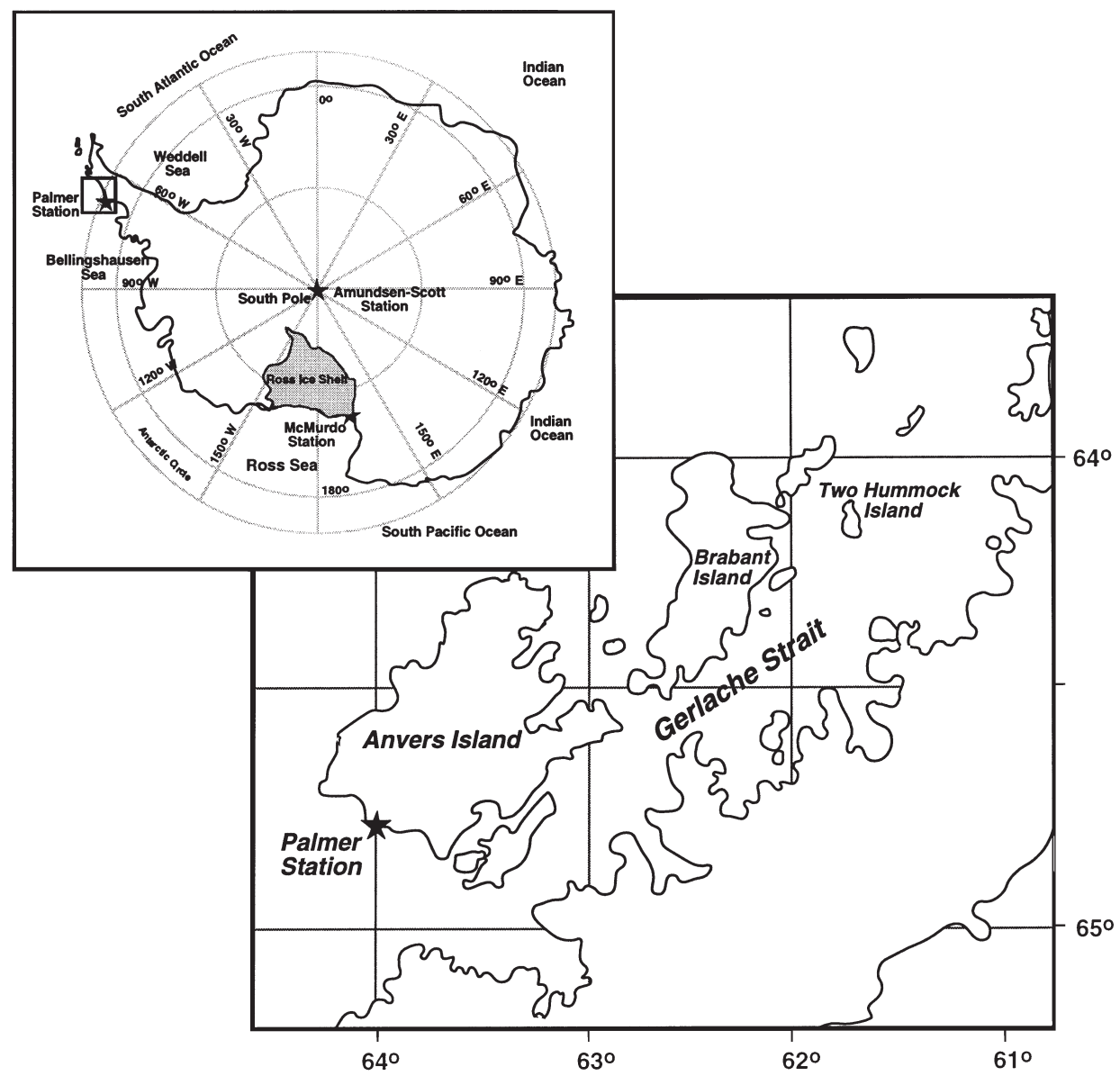

Fig. 1. Map of the Gerlache Strait, Antarctica

pak, Nasco, Modesto, California) with high UV-B transmittance (Aas et al. 1996) containing filter-sterilized $(0.2 \mu \mathrm{m})$ seawater were inoculated to an optical density, $\mathrm{OD}_{600}$, of 0.6 with overnight cultures of RM11001. Triplicate samples were placed in flow-through seawater incubators on the helo deck of the RV 'Polar Duke', where shading was negligible. Incubators were $60 \mathrm{~cm}$ square, $1.5 \mathrm{~cm}$ high, and were constructed of UV-transparent acrylic. Sides were $0.5^{\prime \prime}(\sim 1.27 \mathrm{~cm})$ thick while the lids had a thickness of $0.25^{\prime \prime}(\sim 0.64 \mathrm{~cm})$. Flowthrough seawater provided by the ship's seawater system kept temperature parameters within $0.1^{\circ} \mathrm{C}$ of ambient seawater. When appropriate, filters to eliminate various parts of the UV solar spectrum were fitted onto the tanks. Whirlpak bags were sampled for RecA protein, cell counts, and viability counts periodically.

Studies were conducted between October 20 and 23, 1996 , to investigate the induction of recA-gene expression in response to solar UVR. In this experiment, 4 microcosms were established. One microcosm (I) was exposed to full solar radiation (exposed to UV-B, UV-A, and PAR); the second (Microcosm II) was covered with mylar 5000 to remove UV-B wavelengths (exposed to UV-A and PAR); the third (Microcosm III) was constructed of UF-3 Plexiglas to remove both UV-B and UV-A (exposed to PAR only); the final microcosm (IV) was incubated in the dark (unexposed control). Fifteen triplicate samples were prepared and treated by exposing them to full sun for $2 \mathrm{~h}$. Viability was determined before and after this treatment. This treatment was followed by placing triplicate sets of cultures under various light regimes specified by Microcosms I to IV for another $6 \mathrm{~h}$. All samples were then placed in the dark and incubation was continued for an additional $48 \mathrm{~h}$ to allow recovery.

Enumeration of bacteria from seawater microcosms. Viable counts (CFU) were determined after cells were diluted in $1.5 \% \mathrm{NaCl}$ sterile saline by 10 -fold dilutions. One-tenth milliliter samples were spread-plated onto seawater medium (autoclaved seawater containing $1.5 \%$ agar, $0.05 \%$ casamino acids, and $0.05 \%$ bactopeptone; Difco Laboratories, Detroit, Michigan). Plates were incubated overnight at room temperature and CFU determined. 
Epifluorescence direct counts were determined by DAPI (4', 6-diaminidino-2-phenylindiole) with the method of Porter \& Feig (1980) using a Nikon (Melville, New York) Labophot-2 \& 2e epifluorescence microscope.

Protein assays. Bacterial total proteins were extracted from either frozen polycarbonate filters into protein extraction buffer (PEB: $50 \mathrm{mM}$ Tris- $\mathrm{HCl}, 2 \%$ SDS, and $10 \%$ glycerol; $\mathrm{pH} 6.8$ ) by placing them in boiling water for 5 to $10 \mathrm{~min}$. Lowry protein assays were performed to determine protein concentration using the BioRad DC Protein Assay Kit (BioRad, Hercules, California) according to manufacturer recommendations.

Preparation and electrophoresis of cell lysates of RM11001. Cross-reactivity of purified Escherichia coli RecA antigen with RM11001 was assayed by Western analysis. Cell lysates were prepared by collecting $10 \mathrm{ml}$ of an RM11001 culture in exponential growth phase (60 to 80 Klett $_{660}$ units). This sample was centrifuged for $5 \mathrm{~min}$ at $4300 \times g$ at room temperature. The cell pellet was suspended in $300 \mu \mathrm{l}$ PEB, and placed in a boiling water bath for 5 to $10 \mathrm{~min}$. Protein concentrations were determined. Three micrograms of total cellular protein was loaded onto a $12 \%$ SDS-polyacrylamide gel and electrophoresed at $100 \mathrm{~V}$ for $1.5 \mathrm{~h}$. Protein from E. coli Strain AB1157 was included as a positive control.

Western analysis of RecA. Immunological assessment of the concentration of RecA protein in total protein extracts was in general conducted as described by Miller \& Kokjohn (1988). Anti-Escherichia coli RecA antibody was used as the primary antibody. It was generously supplied by S. Kowalscykowski (University of California at Davis) initially. In later experiments, polyclonal anti-RecA antibody were prepared at the OSU Hybridoma Center (Stillwater, Oklahoma). Protein extracts to be assayed were transferred to Immobilon ${ }^{\mathrm{TM}}-\mathrm{P}$ PVDF membrane (Millipore, Bedfore, Massachusetts) by electroblotting using a Mini Trans-Blot Cell as recommended by the manufacturer (BioRad). Western analysis was done utilizing a BioRad Immune-Lite kit (BioRad). The primary antibody was used at a ratio of 1:5000 and incubated for $4 \mathrm{~h}$.

Assay of RecA protein levels in seawater communities. Proteins were immobilized onto PVDF membranes using a Schleicher and Schuell slot blotter. A dilution series $\left(5,2.5,1.25,0.625\right.$, and $\left.0.3125 \mu \mathrm{ml}^{-1}\right)$ in $1 \times$ TBS (20 mM Tris, $500 \mathrm{mM} \mathrm{NaCl}$, pH 7.4) or a specified concentration (either 2.5 or $10 \mu \mathrm{ml}^{-1}$ ) of protein was applied in $0.5 \mathrm{ml}$ vol. to the membrane using a Minifold II Slot-Blot System (Schleicher \& Schuell, Keene, New Hampshire). Membranes with immobilized proteins were analyzed by Western immuno-blotting using the Immune-Lite ${ }^{\mathrm{TM}}$ kit (BioRad) according to manufacturer specifications. After chemiluminescent development and autoradiography, the intensity of the reaction was quantified using a laser densitometer with the Molecular Analyst Molecular Imaging System (BioRad). Densitometry allowed quantification of the amount of antigen-antibody complex as relative optical density units (ODU). Regression analysis was performed on the dilution series to establish a correlation between ODU and the concentration of total protein in the cellular extracts. The RecA signal was related to the amount of total protein by linear regression with a regression coefficient $\left(\mathrm{r}^{2}\right)$ of $\geq 0.9$. Quantities of samples that were not diluted were taken directly from the densitometric output.

PCR amplification and sequencing of $\operatorname{recA}$ sequences from Antarctic isolates. PCR amplification of the recA sequences in RM11001 and other Antarctic isolates was carried out by the methods and using the primers described by van Waasbergen et al. (2000). Sequence analysis was done on an Applied Biosystems automated DNA sequencer, Model 373A.

Assay for $\boldsymbol{r e c A}$-specific mRNA. For each time point, four, 21 surface-water samples were collected and filtered onto $0.22 \mu \mathrm{m}$ pore-size Sterivex (Millipore) filters kept in $\mathrm{a}-2^{\circ} \mathrm{C}$ bath and immediately frozen at $-80^{\circ} \mathrm{C}$ once filtration was complete. RNA was extracted, blotted, and probed as described in Jeffrey et al. (1994). The probe was produced from a $181 \mathrm{bp}$ region of the cloned Pseudomonas aeruginosa recA gene (Kokjohn $\&$ Miller 1987). This $181 \mathrm{bp}$ region was chosen because it is within the most highly conserved sequence of the gene in eubacteria (Miller 2000).

\section{RESULTS AND DISCUSSION}

\section{Induction of RecA in natural Antarctic bacterio- plankton assemblages}

Total bacterial (DAPI) cell counts from surface-water samples averaged $1.6 \pm 0.56 \times 10^{5}$ cells ml $^{-1}(\mathrm{n}=31)$. The levels of RecA antigen in the bacterioplankton community was determined from samples taken every $2 \mathrm{~h}$ for a $24 \mathrm{~h}$ period. Data from the experiments conducted each year (4 in 1995 and 5 in 1996) during the austral spring were averaged. Figs. 2 \& 3 illustrate detectable levels of RecA antigen in natural bacterioplankton populations receiving ambient sunlight. Generally, similar results were observed in 1995 and 1996. RecA antigen accumulated during the day and early evening and dropped again by morning. Higher RecA induction levels observed in 1996 may reflect a different bacterial assemblage present in the straits in the 2 yr studied. Bacterial numbers and production were generally higher in 1996 than in 1995 (Jeffrey et al. unpubl. data).

RecA noticeably dropped in the afternoon in all experiments. We observed a similar drop in bacterio- 
plankton collected from the Gulf of Mexico (Booth et al. 2001, Miller et al. unpubl. data). The late-afternoon drop in RecA concentration is most likely to have been due to the interplay of photoreactivation 'light repair' which requires visible light of wavelengths between 380 and $450 \mathrm{~nm}$ as a cofactor (Jagger 1985). During the afternoon visible light is plentiful and photoreactivation is capable of repairing the damage experienced by a cell. However, as the levels of sunlight are attenuated in late afternoon, the ability of the light repair mechanism to eliminate thymine dimers is severely reduced and finally eliminated. Even though damage rates also decrease as UV radiation is attenuated, RecA-mediated dark repair (Miller 2000) becomes the only means of eliminating the remaining damage. This led to heightened recA-gene expression in late afternoonearly evening. These data agree with our earlier studies (Jeffrey et al. 1996b, Lyons et al. 1997, Booth et al. 2001) demonstrating that un-repaired thymine dimers remaining at sunset decrease and return to background levels by sunrise. Taken together, these observations suggest that unrepaired lesions are corrected by dark repair in marine bacterioplankton.

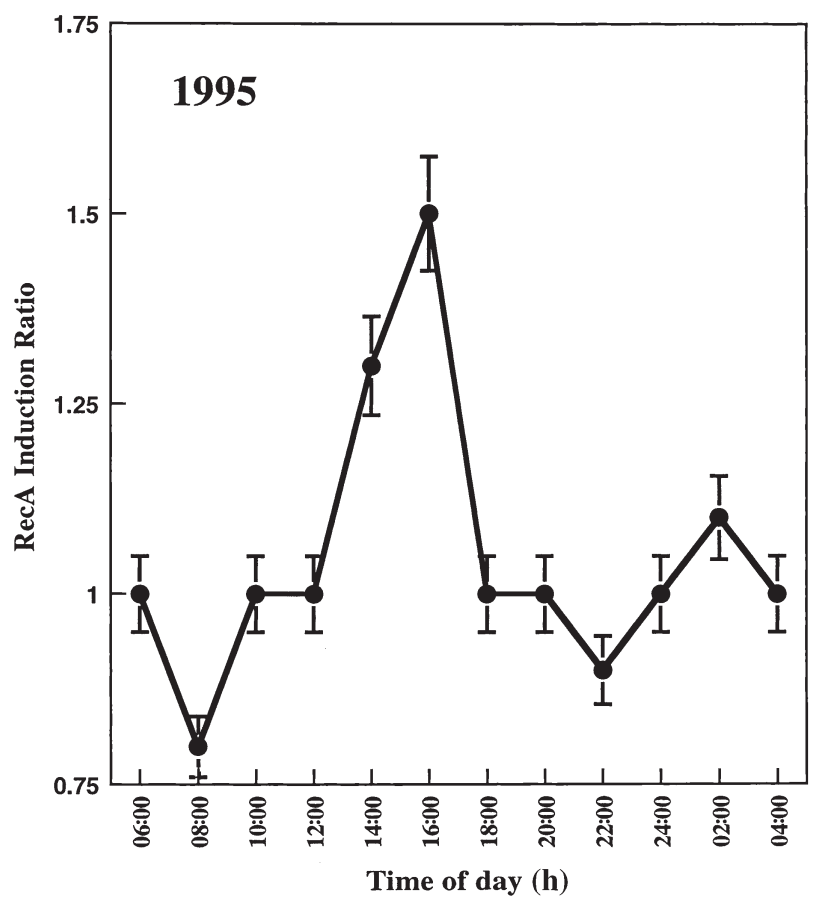

Fig. 2. RecA protein induction over $24 \mathrm{~h}$ in natural marine bacterioplankton in 1995. Four diel experiments were averaged. Surface samples were collected every $2 \mathrm{~h}$ for $24 \mathrm{~h}$ for each experiment. The induction ratio (IR) represents the amount of RecA (optical density units $\mu^{-1}$ total protein) at each time point relative to the amount in the first sample. Standard errors of the means are shown. During the period of these experiments, sunrise varied from 05:00 to 06:00 $\mathrm{h}$ and sunset from 18:00 to $20: 00 \mathrm{~h}$

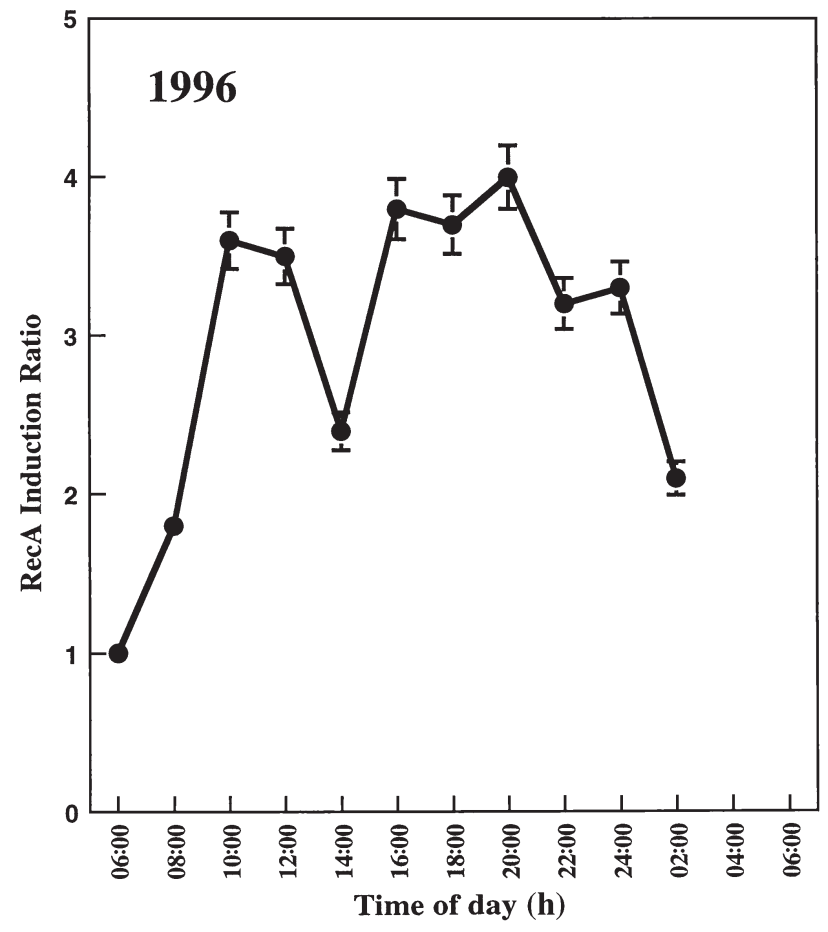

Fig. 3. RecA protein induction over $24 \mathrm{~h}$ in natural marine bacterioplankton in 1996. Five diel experiments were averaged. Surface samples were collected every $2 \mathrm{~h}$ for $24 \mathrm{~h}$ for each experiment. Standard errors of the means are shown. During the period of these experiments, sunrise varied from 05:00 to 06:00 $\mathrm{h}$ and sunset from 18:00 to $20: 00 \mathrm{~h}$

\section{Induction of RecA at the transcriptional level}

To determine if the increased levels of RecA protein observed were due to increased transcription of the recA gene, we examined diel patterns of recA-specific mRNA transcription. A pattern similar to that of RecA protein was observed in the recA-specific mRNA that hybridized to our probe (Fig. 4), indicating that the diel pattern observed in RecA protein was due to increased transcriptional activity of the recA gene, presumably in response to the levels of un-repaired DNA damage in the cell.

\section{Diel induction of RecA in an Antarctic marine bacterial isolate}

Several bacterial strains were isolated from seawater collected in the Gerlache Strait. The isolates were found to be Gram-negative aerobes capable of surviving within a wide temperature range on various rich media. BIOLOG (BIOLOG Inc., Hayward, California) analysis indicated that the organisms belonged to a $\gamma$-proteobacter. Examples of organisms within this sub- 


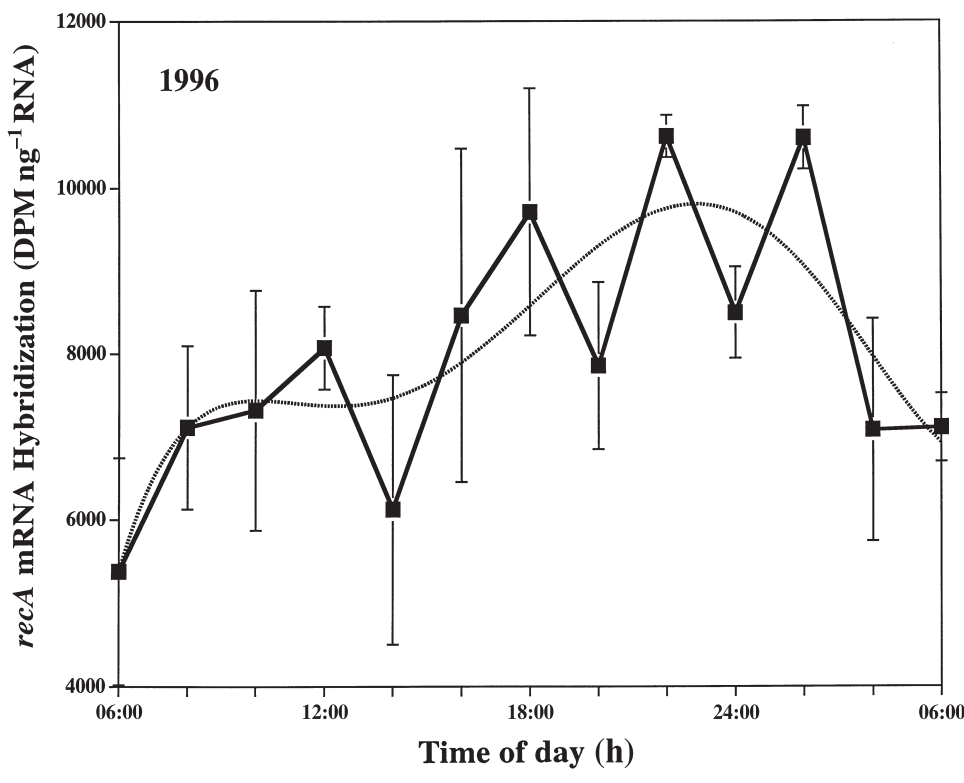

Fig. 4. Diel pattern of recA transcription in the Gerlache Strait, Antarctica, surface waters on October 4/5, 1996. Data are the average of 4 replicate filters $\pm \mathrm{SD}$. Curve fit is polynomial $\left(\mathrm{r}^{2}=0.634\right)$ and is used to represent the small morning peak often observed prior to the large induction peak observed after sunset. At the time of this experiment, sunrise was at 06:00 h and sunset at 18:00 h

division are the genera Vibrio, Hemophilus, Proteus and Pseudomonas.

One of these organisms, designated RM11001, was chosen for further study. Western analysis using antiEscherichia coli RecA polyclonal antisera demonstrated that the organism contained a strong cross-reactive protein with an approximate $40 \mathrm{kDa}$ molecular mass (Fig. 5). This molecular size agrees with that of RecA proteins isolated from numerous species of bacteria (Miller \& Kokjohn 1988, 1990, Miller 2000). Similar analysis of the other Antarctic isolates demonstrated that they contained similar, cross-reactive proteins (data not shown).

Partial sequence analysis of the RM11001 recA gene was carried out using primers and methods described by van Waasbergen et al. (2000). This analysis confirmed the BIOLOG designation of the organism as a $\gamma$-proteobacter. As definitive identification was unnecessary for this study, further sequence characterization was not done.

The results of the experiments examining diel profiles of recA-gene expression in RM11001 are shown in Fig. 6. RM11001 exhibited RecA induction in response to both full sunlight and to exposure to only UV-A and PAR light. However, induction levels in microcosms exposed to only UV-A and PAR light were significantly lower than the levels detected in response to full sunlight. No induction of RecA was ob- served in the dark control or when the cells were exposed to only PAR.

We have previously investigated RecA response in the marine bacterium Vibrio natriegens in Gulf of Mexico microcosms (Booth et al. 2001). Similar recA-induction patterns were observed with $V$. natriegenes as were observed with RM11001. However, RM11001 demonstrated substantially lower mortality and higher RecA induction than did $V$. natriegens.

\section{Determination of relative importance of light and dark repair mechanisms in RM11001}

A second microcosm study was conducted to elucidate whether RM11001 relied more on light repair or RecA-mediated dark repair for survival. In addition, these experiments were designed to determine whether UV-A as well as UV-B wavelengths were impacting RM11001 (Fig. 7).

Cell viability decreased over the $48 \mathrm{~h}$ dark recovery period in cultures exposed to full sunlight. Interestingly, cells exposed to PAR and UVA (UV-B excluded) recovered as efficiently as those placed in the dark after pre-treatment. Likewise, cultures exposed to only PAR recovered only slightly more efficiently. While these

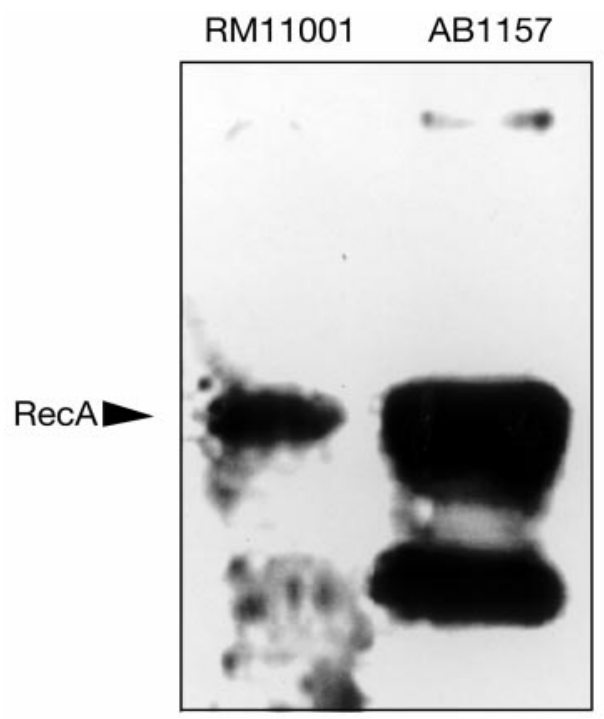

Fig. 5. Western blot of RecA protein from Escherichia coli AB1157 and Antarctic isolate RM11001. Anti-E. coli RecA antisera was used. RecA protein is shown as a 40000 molecular weight band in each bacterial protein extract. The lower molecular weight band in the E. coli sample has been shown to be an oxidation product of the RecA protein, while higher molecular weight bands are polymers of the protein (Miller \& Kokjohn 1988) 


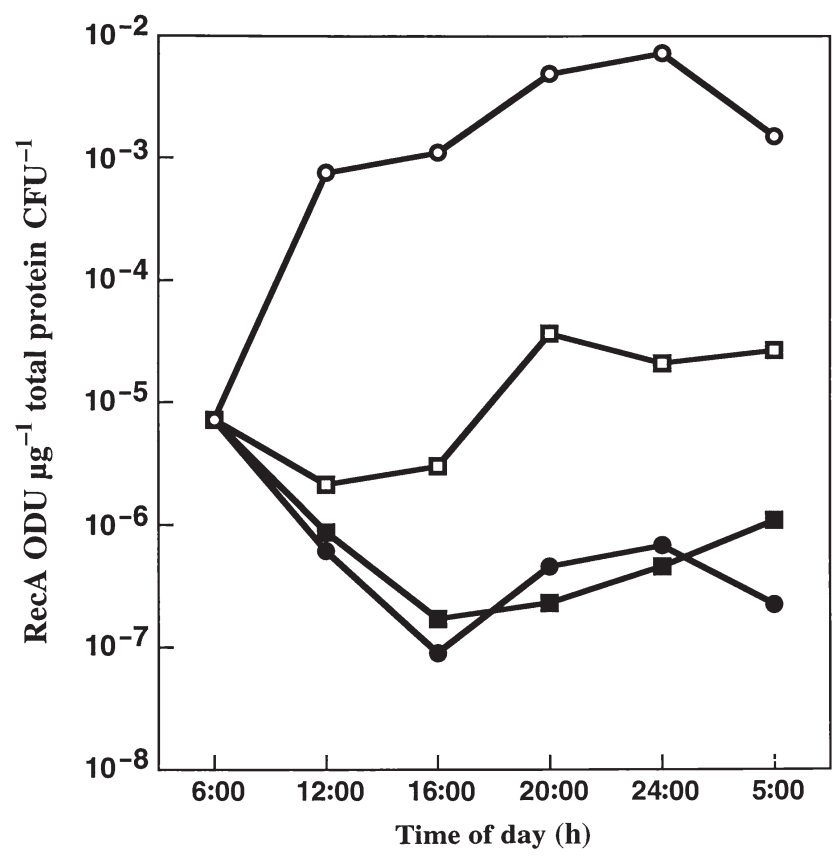

Fig. 6. RecA protein induction in response to solar UV radiation in an Antarctic marine isolate. Triplicate cultures of RM11001 were placed under different light treatments and sampled every $4 \mathrm{~h}$ for $24 \mathrm{~h}$ for viability and production of RecA protein. (O) ambient sunlight; (๑) dark control; ( $\square$ ) UVB filtered light; ( $\mathbf{\square})$ UV radiation (UV-A and UV-B) filtered light. Error bars for the standard error of the mean were smaller than the symbols

data do not clearly indicate whether photoreactivation played a predominant role in DNA repair, they clearly demonstrate that RM11001 is negatively impacted by the UV-B portion of the spectrum.

\section{General observations}

In this study, natural Antarctic bacterial assemblages showed induction of RecA protein and $r e c A$-specific mRNA in a diel pattern that

Fig. 7. Recovery of viability of RM11001. Fifteen triplicate cultures were treated by exposing them to full sunlight for $4 \mathrm{~h}$. One triplicate set was destructively sampled after exposure and the remaining sets were placed under various light regimes for 6 additional hours. After the $6 \mathrm{~h}$ treatment, all samples were moved into dark incubation and sampled periodically as indicated for $48 \mathrm{~h}$. Unexposed controls $(\star)$ were left in the dark through the entire experiment. Light regime during treatment period was: (๑) full sunlight; (O) no sunlight; ( $\square$ ) UV radiation-filtered (UV-A and UV-B) light; () UV-B-filtered light increased throughout the day and decreased at night. We observed increases in RecA antigen concentrations in the morning followed by an afternoon decline. This was followed by a burst of recA-gene expression after sunset. Concentrations of RecA protein steadily declined throughout the night. Consistent with these observations, measurement of solar-induced DNA damage in these communities by competitive radioimmunoassay has demonstrated that the highest level of damage occurred at 18:00 $\mathrm{h}$ and was eliminated (presumably by dark repair) during the night (Jeffrey et al. unpubl. data).

Although generally similar, the details of this pattern were muted in microcosm studies using an Antarctic isolate, RM11001. However, samples were taken less often in studies with RM11001 and it is not clear whether these altered patterns reflect true differences or are artifacts of the sampling regime. Microcosm studies using Vibrio natriegens in the Gulf of Mexico more closely mimic the diel patterns observed in Antarctic assemblages (Booth et al. 2001) with maximal induction immediately after sunset.

\footnotetext{
.
}
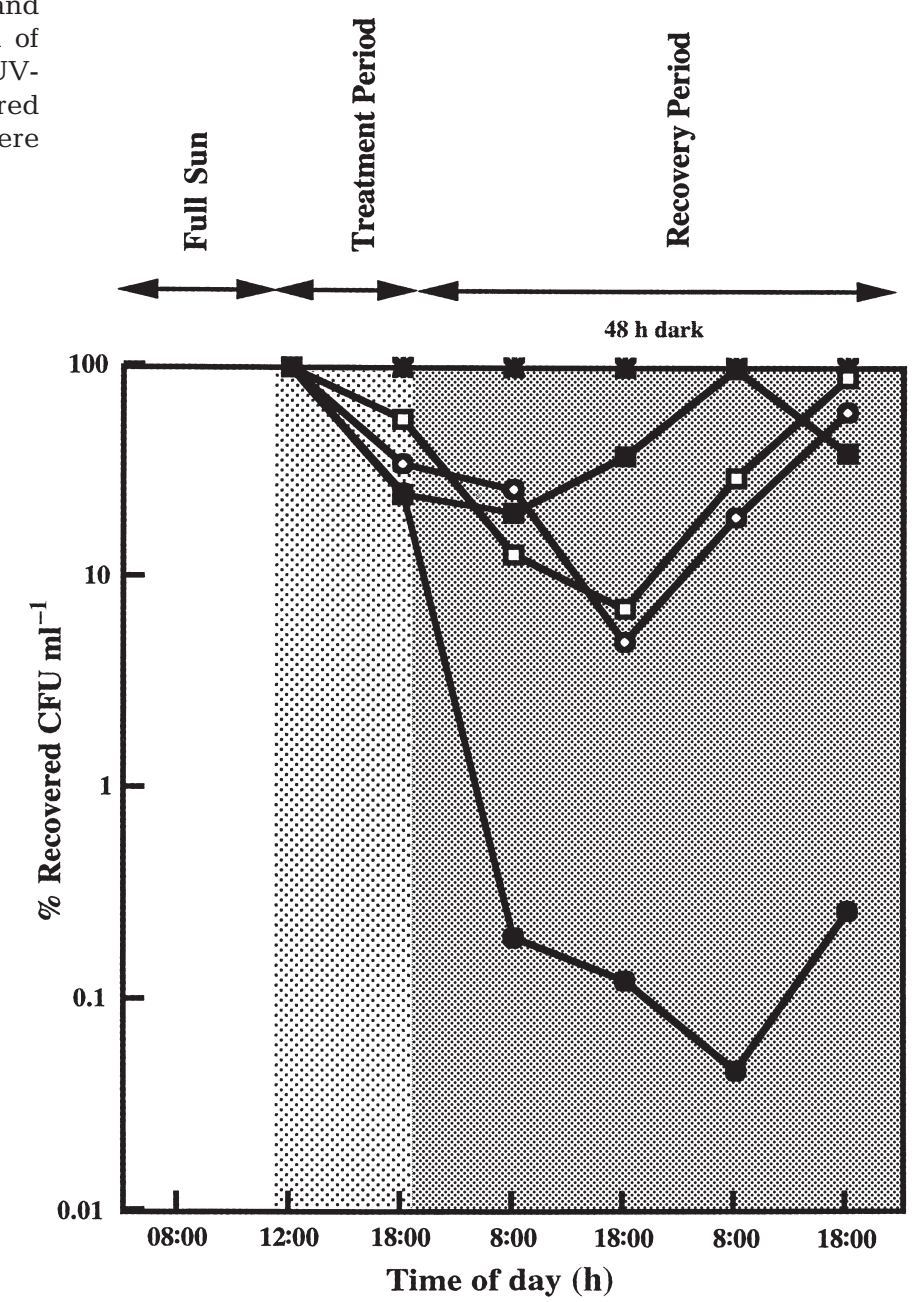
recA-gene expression may not be as tightly regulated in RM11001 as in Escherichia coli and many other microorganisms (Miller 2000). The apparent high level of constitutive recA-gene expression in RM11001 may be an adaptation to its environment. Accumulation of thymine dimers was not detected in RM11001 (data not shown), suggesting that thymine-dimer repair in this Antarctic isolate is highly efficient under ambient conditions. In any case, RecA is still heavily recruited for DNA repair of sunlight-induced lesion in RM11001, as concentrations of RecA protein in tanks receiving full sunlight were much higher than in those receiving filtered or no light.

RM11001 also differed from Vibrio natriegens in its response to UV-A (Booth et al. 2001). V. natriegens induces RecA and suffers mortality almost equally in response to light containing only UV-A and to light in which UV-A and UV-B are both present. RM11001 is more tolerant of UV-A, suggesting that other mechanisms (perhaps light repair) may be more efficient in repairing UV-A induced lesions in this organism.

Undoubtedly, various residents of the marine microbial community have different tolerances and defenses to solar UV radiation (Helbling et al. 1995, Joux et al. 1999, Arrieta et al. 2000). RM11001 must tolerate different periods of UV radiation during the Antarctic spring and summer and as a result of thinning ozone than does the sub-tropical Vibrio natriegens isolate. RM11001 may have adapted by evolving more efficient visible-light-dependent repair mechanisms or oxidative protection systems (Peak \& Peak 1989).

Heterotrophic bacterioplankton function as active players in uptake and recycling of nutrients required for primary production at the very base of the pelagic food web. UV radiation negatively impacts bacterioplankton as well as other trophic levels. Studies to investigate the possible consequences to marine food webs indicate that bacterioplankton are not necessarily enhanced by removing UV-B, but that a decrease in grazers relative to bacteria may result in an overall increase in heterotrophic bacterial carbon biomass (Wickham \& Carstens 1998, Mostafir et al. 1999). Coping mechanisms, such as DNA repair efficiency, among predators and prey, i.e. grazers and bacteria, may give different groups a selected advantage in times of environmental stress. Evaluating the efficiency of defenses and coping mechanisms such as DNA repair of various trophic levels will allow us to more accurately predict the impacts of UV radiation on marine food webs.

Acknowledgements. We thank Steve Ripp, Erin McKee, and Jason Kase for assistance in the field. We are indebted to the captain and crew of the RV 'Polar Duke' for their outstanding operations in the Southern Ocean. Special thanks to Antarctic
Support Associates for providing technical and field assistance. This work was supported by National Science Foundation Office of Polar Programs awards OPP-9801784 to R.V.M and OPP-9419037 and OPP-9727319 to W.H.J.

\section{LITERATURE CITED}

Aas P, Lyons MM, Pledger R, Mitchell DL, Jeffrey WH (1996) Inhibition of bacterial activities by solar radiation in nearshore waters and the Gulf of Mexico. Aquat Microb Ecol 11:229-238

Arrieta JM, Weinbauer MG, Herndl GJ (2000) Interspecific variability in sensitivity to UV radiation and subsequent recovery in selected isolates of marine bacteria. Appl Environ Microbiol 66:1468-1473

Bidigare RR (1989) Potential effects of UV-B radiation on marine organisms of the southern Ocean: distributions of phytoplankton and krill austral spring. Photochem Photobiol 50:469-477

Booth MG, Jeffrey WH, Miller RV (2001) RecA expression in response to solar UVR in the marine bacterium Vibrio natriegens. Microb Ecol (in press)

Farman JC, Gardiner BG, Shanklin JD (1985) Large losses of total ozone in Antarctica reveal seasonal $\mathrm{CLO}_{\mathrm{x}} / \mathrm{NO}_{\mathrm{x}}$ interactions. Nature 315:207-210

Forster RM, Lüning K (1996) Photosynthetic response of Laminaria digitata to ultraviolet-A and ultraviolet-B radiation. Sci Mar 60:65-71

Gudas LJ, Pardee AB (1976) DNA synthesis inhibition and the induction of protein X in Escherichia coli. J Mol Biol 101: 459-477

Helbling EW, Marguet ER, Villafañe VE, Holm-Hansen O (1995) Bacterioplankton viability in Antarctic waters as affected by solar ultraviolet radiation. Mar Ecol Prog Ser 126:293-298

Herndl GM, Miller-Niklas G, Frick J (1993) Major role of ultraviolet-B in controlling bacterioplankton growth in the surface layer of the ocean. Nature 361:71-72

Herrmann H, Hader DP, Ghetti F (1997) Inhibition of photosynthesis by solar radiation in Dunaliella salina: relative efficiencies of UV-B, UV-A and PAR. Plant Cell Environ 20:359-365

Holm-Hansen O (1997) Short- and long-term effects of UVA and UV-B on marine phytoplankton productivity. Photochem Photobiol 65:266-267

Holm-Hansen O, Helbing EW, Lubin D (1993) Ultraviolet radiation in Antarctica: inhibition of primary production. Photochem Photobiol 58:567-570

Imlay JA, Linn S (1988) DNA damage and oxygen radical toxicity. Science 240:1302-1309

Jagger J (1985) Solar-UV actions on living cells. Praeger Publishers, New York

Jeffrey WH, Nazaret S, von Haven R (1994) Improved method for the recovery of mRNA from aquatic samples: application to detecting mer gene expression. Appl Environ Microbiol 60:1814-1821

Jeffrey WH, Lyons MM, Coffin RB, Pledger RJ, Mitchell DL (1996a) Ambient solar radiation-induced photodamage in marine bacterioplankton. Photochem Photobiol 64: 419-427

Jeffrey WH, Pledger RJ, Aas P, Hager S, Coffin RB, von Haven R, Mitchell DL (1996b) Diel and depth profiles of DNA photodamage in bacterioplankton exposed to ambient solar ultraviolet radiation. Mar Ecol Prog Ser 137: 283-291

Joux F, Jeffrey WH, Lebaron P, Mitchell DL (1999) Marine 
bacterial isolates display diverse responses to UV-B radiation. Appl Environ Microbiol 65:3820-3827

Kokjohn TA, Miller RV (1987) Characterization of the Pseudomonas aeruginosa recA analog and its protein product: rec-102 is a mutant allele of the $P$. aeruginosa $\mathrm{PAO}$ recA gene. J Bacteriol 169:1499-1508

Lyons MM, Aas P, Pakulski JD, van Waasbergen L, Miller RV, Mitchell DL, Jeffrey WH (1997) DNA damage induced by ultraviolet radiation in coral-reef microbial communities. Mar Biol 130:537-543

Marchant HJ, Davidson, AT, Kelly GJ (1991) UVR-protection compounds in the marine algae Phaeocystis pouchetti from Antarctica. Mar Biol 109:391-395

Miller RV (2000) recA: the gene and its protein product. In: Luria S (ed) Encyclopedia of microbiology, 2nd edn, Vol 4. Academic Press, San Diego, p 43-54

Miller RV, Kokjohn TA (1988) Expression of the recA gene of Pseudomonas aeruginosa PAO is inducible by DNA-damaging agents. J Bacteriol 170:2385-2387

Miller RV, Kokjohn TA (1990) General microbiology of recA: environmental and evolutionary significance. Annu Rev Microbiol 44:365-394

Miller RV, Ku CMC (1978) Characterization of Pseudomonas aeruginosa mutants deficient in the establishment of lysogeny. J Bacteriol 134:875-883

Miller RV, Jeffry W, Mitchell D, Elasri M (1999) Bacterial responses to ultraviolet light: increased UV flux may be damaging microorganisms at the poles and thereby disrupting an ecology with important global impacts. ASM News 65:535-541

Mostafir B, Demers S, de Mora S, Belzile C, Chanut JP, Gosselin M, Roy S, Villegas PZ, Fauchot J, Bouchar J (1999) Experimental test of the effect of ultraviolet-B radiation in a planktonic community. Limnol Oceanogr 44:586-596

Ochsner UA, Vasil ML, Alsabbagh E, Parvatiyar K, Hassett DJ (2000) Role of the Pseudomonas aeruginosa osyR-recG operon in oxidative stress defense and DNA repair: oxyRdependent regulation of $k a t B-a n k B, a h p B$, and $a h p C$ -

Editorial responsibility: James Hollibaugh, Athens, Georgia, USA
ahpF. J Bacteriol 182:4533-4544

Peak MJ, Peak JG (1989) Solar-ultraviolet-induced damage to DNA Photodermatol Photoimmunol Photomed 6:1-15

Porter KG, Feig YG (1980) The use of DAPI for identifying and counting aquatic microflora. Limnol Oceanogr 25:943

Schick JM, Lesser MP, Dunlap WC, Stochaj WR, Chalker BE, Won JW (1995) Depth-dependent responses to solar ultraviolet radiation and oxidative stress in the zooxanthellate coral Aoropora microphthalma. Mar Biol 122:41-51

Solomon S, Garcia RR, Rowland FS, Wuebbles DJ (1986) On the depletion of the Antarctic ozone. Nature 321:755-758

Stamnes K, Slusser J, Bowen M, Booth C, Lucas T (1990) Biologically effective ultraviolet radiation, total ozone abundance, and cloud optical depth at McMurdo station, Antarctica Setptember 151988 through April 15 1989. Geophys Res Lett 17:2181-2184

Stolarski RS (1988) The Antarctic ozone hole. Sci Am 258: $30-36$

van Waasbergen LG, Balkwill DL, Crocker FH, Bjornstad BN, Miller RV (2000) Genetic diversity among Arthrobacter species collected across a heterogeneous series of terrestrial deep-subsurface sediments as determined by $16 \mathrm{~S}$ rRNA and recA gene sequences. Appl Environ Microbiol 66:3454-3463

Visser PM, Snelder E, Kop AJ, Boelen P, Buma AGJ, van Duyl FC (1999) Effects of UV radiation on DNA photodamage and production in bacterioplankton in the coastal Caribbean Sea. Aquat Microb Ecol 20:49-58

Walker GC (1984) Mutagenesis and induced responses to deoxyribonucleic acid damage in Escherichia coli. Microbiol Rev 48:60-93

Wickham S, Carstens M (1998) Effects of ultraviolet-B radiation on two arctic microbial food webs. Aquat Microb Ecol 16:163-171

Zagarese HE, Feldman M, Williamson CE (1997) UV-B-induced damage and photoreactivation in three species of Boeckella (Copepoda, Calanoida). J Plankton Res 19: 357-367

Submitted: September 15, 2000; Accepted: November 22, 2000 Proofs received from author(s): March 13, 2001 